\title{
EWOLUCJA STUDIÓW DOKTORANCKICH - OD POLITECHNIKI SZCZECIŃSKIEJ DO UNIWERSYTETU SZCZECIŃSKIEGO
}

\author{
Józef Perenc \\ Wydział Zarządzania i Ekonomiki Usług, Uniwersytet Szczeciński
}

\section{WPROWADZENIE}

Wiele polskich uczelni, w tym także Politechnika Szczecińska a później Uniwersytet Szczeciński, za najważniejszy zasób uważają swoje kadry. Droga zawodowa od asystenta do samodzielnego pracownika jest długa, a jednym z ważnych stopni na tej drodze jest doktorat. Napisanie pracy doktorskiej może się odbywać w trybie eksternistycznym lub regularnych studiów doktoranckich. Po 15 latach funkcjonowania Politechniki Szczecińskiej w 1970 roku zdecydowano o powołaniu zaocznego studium doktoranckiego na Wydziale Ekonomicznym, a później także na Wydziale Inżynieryjno-Ekonomicznym Transportu. Doktorat to ważna rozprawa, która powinna być samodzielnym, oryginalnym rozwiązaniem problemu naukowego, wykazywać ogólną wiedzę kandydata w danej dyscyplinie. Doktorant powinien wnieść swoistą cegiełkę do „skarbnicy wiedzy”.

\section{POTRZEBA POWOŁANIA STUDIUM DOKTORANCKIEGO W POLITECHNICE SZCZECIŃSKIEJ}

Politechnika Szczecińska - uczelnia z sześcioma wydziałami, z ponad 16 tys. studentów i około 800 pracowników naukowo-dydaktycznych - potrzebowała do ćwiczeń, laboratoriów, proseminariów nowych doktorów, w tym także z nauk ekonomicznych. Oprócz trybu eksternistycznego, który dominował przy naborze pracowników zewnętrznych, od 1970 roku uruchomiono tryb studiów doktoranckich zaocznych. Po ogłoszeniu naboru w kolejnych latach zgłaszało się około 20-40 kandydatów na te studia. Każdy kandydat pisał esej wstępny, odpowiadał na pytania komisji kwalifikacyjnej, a po zakwalifikowaniu około 24-30 kandydatów rozpoczynało studia w trybie comiesięcznych zjazdów. Kierowanie I studium doktoranckim rada wydziału powierzyła prof. dr Przemysławowi Małkowi. Kolejno powołanym studium doktoranckim od 1971 roku kierował ${ }^{1}$ Profesor Franciszek Gronowski. W tym roku nasz Jubilat kończy 90 lat życia. Jest więc okazja, aby przywołać okres 1971-1975 i dalsze lata z jego bardzo aktywnego

1 Kolejnymi kierownikami Studiów Doktoranckich byli na WTiŁ oraz na WZiEU profesorowie: W. Grzywacz, J. Engelhardt, J. Perenc, H. Babis, S. Flejterski, E. Załoga, K. Brzozowska. 
życia, jego życiowych dokonań oraz ukazać jak przebiegała ewaluacja studiów doktoranckich na Politechnice Szczecińskiej i Uniwersytecie Szczecińskim.

Obecność w Szczecinie na tym święcie wielu naukowców, wielu praktyków szeroko rozumianej branży morskiej jest wyraźnym dowodem szacunku, poważania i uznania dokonań Profesora Franciszka Gronowskiego.

\section{NABÓR I DECYZJA O PRZYJĘCIE NA STUDIA DOKTORANCKIE}

Po ogłoszeniu naboru na zaoczne studia doktoranckie wiele instytutów naukowo-badawczych, dyrektorzy katedr i instytutów uczelnianych, kierownicy (dyrektorzy) ważnych w polskiej gospodarce przedsiębiorstw skierowali do Politechniki Szczecińskiej na studia doktoranckie swoich pracowników. Zrobili to między innymi Zarząd Portu Szczecin-Świnoujście, Baltona, Polska Żegluga Morska, PKP, Poczta Polska, Hartwig, PZU, Ośrodek Badawczy Ekonomiki Transportu, Instytut Transportu Samochodowego, Instytut Morski i wiele innych podmiotów.

Kandydaci mieli tytuł magistra lub inżyniera. Po napisaniu około 10 stron esejów i ich obronie oraz rozmowie kwalifikacyjnej odbyła się kwalifikacja kandydatów. Następnie Komisja Naboru kierowała wniosek do Rektora o przyjęcie i uruchomienie studiów doktoranckich. Według wtedy istniejących uregulowań prawnych, zakłady pracy, które kierowały na te studia swoich pracowników powinny doktorantom udzielać urlopów szkoleniowych, dopomagać im w wyborze tematów rozpraw oraz w miarę możliwości wspomagać ich w pokrywaniu części kosztów tych studiów. Pracownicy delegowani na te studia przez uczelnie oraz przez instytuty naukowo-badawcze czynili starania, aby bieżące prace naukowo-badawcze choć w części były zbieżne z wybranymi tematami rozpraw doktorskich. W latach 1971-1975 z takiej formy pomocy w grupie 24 doktorantów skorzystało sześć osób (w tym piszący ten artykuł).

\section{EWOLUCJA PROGRAMÓW STUDIÓW DOKTORANCKICH}

Kandydaci którzy zostali zakwalifikowani na te studia w większości byli absolwentami studiów ekonomicznych, ale słuchaczami byli także absolwenci studiów inżynierskich. Istniała więc potrzeba uzupełnienia i wyrównania poziomu wiedzy ekonomicznej. Doktoranci po 2-3 latach zajęć byli zobligowani do zdania trzech egzaminów doktorskich - z ekonomii, filozofii lub socjologii oraz z języka obcego. Bardzo ważnym przedmiotem była ekonomia (makro i mikro), którą wykładali prof. dr hab. J. Rutkowski oraz prof. dr hab. K. Piotrowski. Doktoranci mieli możliwość wysłuchania wykładów z ekonometrii i badań operacyjnych (prowadzonych przez prof. Z. Zielińskiego i prof. J. Hozera) oraz wykładów z filozofii i socjologii. Prowadzono także konwersacje językowe z języka rosyjskiego, niemieckiego i angielskiego. Ważnym blokiem zajęć była i jest metodyka prowadzenia prac doktorskich ${ }^{2}$. W czasie studiów w latach 19711975 zorganizowano siedem grup studiów doktoranckich, które prowadzili: prof. J. Rutkowski, prof. P. Małek, prof. J. Wolszczan, prof. T Wierzbicki, prof. F. Gronowski oraz prof. W. Górski. W niektórych grupach seminaryjnych w zajęciach uczestniczyli doktoranci woluntariusze z tzw. wolnego naboru. Profesor Franciszek Gronowski w tych latach opiekował się: J. Wojsia-

2 Metodykę pracy naukowej prowadzili: prof. W. Grzywacz, prof. S. Flejterski, prof. W. Downar oraz prof. A. Panasiuk. 
tem, W. Nowakiem, B. Lemańczykiem, Z. Sosnowskim, I. Chrzanowskim, K. Luksem, J. Ławickim i innymi doktorantami. Pracownicy Wydziału Inżynieryjno-Ekonomicznego Transportu, pracownicy Wydziału Ekonomicznego a teraz WZiEU po kolejnych awansach naukowych stworzyli możliwość opiekowania się i promowania kolejnych doktorów nauk ekonomicznych. Zajęcia na zaocznych studiach doktoranckich miały za zadanie przygotowanie doktorantów do zdania trzech egzaminów doktorskich. Najważniejszym i trudnym przedmiotem była ekonomia - tak makro jak i mikro, zaś na trzecim roku - „Współczesne problemy globalizacji i konkurencji międzynarodowej”.

Przez trzy lata zaocznych studiów doktoranckich doktoranci mieli możliwość wysłuchania około 290 godz. wykładów, konwersatoriów, seminariów. Od 1985 roku z chwilą rozpoczęcia zajęć na Uniwersytecie Szczecińskim zaistniała możliwość realizacji dziennych studiów doktoranckich $^{3}$. Nasza uczelnia kształtując program zajęć na III poziomie studiów wzorowała się na programach i tzw. siatkach zajęć z takich uczelni jak: Uniwersytet Warszawski, Uniwersytet Jagielloński, Szkoła Główna Handlowa, Uniwersytet Ekonomiczny w Poznaniu, Uniwersytet Gdański, gdyż uczenie te mają dobrze zorganizowane studia doktoranckie, które cieszą się stosunkowo dużym zainteresowaniem doktorantów. Na studia dzienne na Uniwersytecie Szczecińskim byli kierowani młodzi pracownicy naukowi (asystenci) z poszczególnych katedr. Ich obowiązkiem było przeprowadzenie około 60-90 godz. zajęć pod kierunkiem i nadzorem promotora i pracowników samodzielnych odpowiedzialnych za dany wykład.

W roku akademickim 2015/2016 na III poziomie studiów na WZiEU US prowadzone są przedmioty zaprezentowane w tabeli 1.

Tabela 1. Struktura zajęć na I roku zajęć zaocznych studiów doktoranckich na WZiEU US

\begin{tabular}{|c|l|c|c|c|}
\hline Lp. & \multicolumn{1}{|c|}{ Przedmiot } & Liczba godz. & Forma zajęć & Forma zaliczenia \\
\hline 1. & Ekonomia i ekonomia zaawansowana & 30 & $\mathrm{w}$ & $\mathrm{E}$ \\
\hline 2. & Finanse & 30 & $\mathrm{~W}$ & $\mathrm{E}$ \\
\hline 3. & Metodologia nauk ekonomicznych & 30 & $\mathrm{~W}$ & zo \\
\hline 4. & Metodyka nauk ekonomicznych & 30 & $\mathrm{~W}$ & zo \\
\hline 5. & Seminaria doktorskie & 30 & $\mathrm{~s}$ & zo \\
\hline 6. & Statystyczna analiza zjawisk gospodarczych. & 13 & $\mathrm{~W}$ & zo \\
\hline 7. & Informatyka w badaniach naukowych & 15 & $\mathrm{w}$ & zo \\
\hline 8. & Pedagogika i dydaktyka & 48 & $\mathrm{~W}$ & $\mathrm{E}$ \\
\hline 9. & Praktyki zawodowe & 30 & $\mathrm{k}$ & $\mathrm{PR}$ \\
\hline
\end{tabular}

w - wykład, s - seminarium, L - laboratorium, k - konwersatorium, E - egzamin, PR - praktyki, zo - zaliczenie z oceną Przedmioty na drugim roku studiów doktoranckich:

ekonomia - 30 godz., finanse - 30 godz., finanse publiczne - 15 godz., socjologia - 30 godz., język obcy - 15 godz., współczesne koncepcje marketingu - 12 godz., współczesne teorie przedsiębiorstw - 12 godz., wykłady do wyboru - 24 godz., współczesna bankowość - 12 godz., praktyki zawodowe - 30 godz.

Przedmioty na trzecim roku studiów doktoranckich: ekonomia matematyczna - 12 godz., komunikacja interpersonalna 12 godz., język obcy - 15 godz., nowe technologie kształcenia - 12 godz., polityka gospodarcza - 15 godz., seminaria doktorskie - 30 godz., praktyki zawodowe - 30 godz.

3 Na WNEiZ US doktoranci mają możliwość uzyskania doktoratu z ekonomii, zarządzania i z finansów, zaś na WZiEU - z ekonomii oraz finansów. 


\section{POMOCE DYDAKTYCZNE Z METODYKI I METODOLOGII PRAC DOKTORSKICH}

Najbardziej przydatnymi opracowaniami dla doktorantów i promotorów rozpraw doktorskich mogą być:

1. M. Blaug, Metodologia ekonomii, Wydawnictwo Naukowe PWN, Warszawa 1995.

2. M. Sławińska, H. Witczak, Podstawy metodologiczne prac doktorskich $w$ naukach ekonomicznych, PWE, Warszawa 2012.

3. T. Mendel, Metodyka pisania prac doktorskich, AE, Poznań 1996.

4. Z. Leśkiewicz, Paradygmat racjonalności w gospodarowaniu, Wydawnictwo Naukowe US Szczecin 1990.

5. Z. Leśkiewicz, Racjonalność w ekonomii, Wydawnictwo Naukowe US, Szczecin 1994.

Z wymienionych powyżej pozycji na szczególną uwagę i polecenie zasługuje praca M. Sławińskiej i H. Witczaka z Uniwersytetu Ekonomicznego w Poznaniu. Redaktorzy tej monografii skorzystali z bogatego dorobku naukowego, badawczego i naukowego m.in.: M. Goryni, T. Mendla, H. Mruka, M. Ratajczaka, K. Ziemniewicza. Doktoranci i promotorzy z tych prac mogą uzyskać wskazówki dotyczące: ekonomii, nauk o zarządzaniu, problemów stawiania twierdzeń naukowych, stawiania i udowadniania hipotez naukowych, metodyki pisania oraz zasad oceniania rozpraw naukowych. Wskazówki metodyczne są niezmiernie potrzebne i pomocne doktorantom. Metodyczna pomoc promotorów, promotorów pomocniczych powinna im umożliwić udowodnienie, że napisana rozprawa jest oryginalnym rozwiązaniem problemu naukowego, uwidacznia wiedzę teoretyczną kandydata, ukazuje możliwość stawianie hipotez, definiowania celów rozprawy. Rozprawy doktorskie powinny być przykładem logicznego wywodu (rozumowania), jasnego, systematycznego prowadzenia myśli autora, głęboko przemyślanych interpretacji oraz logicznego i twórczego wnioskowania (O twórczym wnioskowaniu pisał też Z. Zakrzewski, 1973, s. 6).

\section{POŻĄDANA PROCEDURA PISANIA DOKTORATÓW ORAZ CECHY DOKTORANTÓW I PROMOTORÓW}

Doktoranci przygotowujący swoje rozprawy w trybie dziennym, zaocznym i eksternistycznym powinni umiejętnie stawiać problemy badawcze, formułować odpowiednie hipotezy, realistycznie określać cele swoich rozpraw. W poszukiwaniu tematów doktoratów ważną rolę pełnią promotorzy oraz promotorzy pomocniczy. Doktoranci powinni dokonywać wyboru swoich opiekunów na początku prac nad doktoratem. Promotor z dużym doświadczeniem naukowym, badawczym może ukazać doktorantom listę problemów, które w danej dyscyplinie warto rozwiązać, wnosząc swój wkład w rozwój teorii i wybranych metod badawczych. Doktorant po wyborze tytułu powinien przygotować podstawowe założenia i koncepcję rozprawy (na około 10 stronach) w których wykaże:

- uzasadnienie wyboru tematu,

- hipotezę główną oraz ewentualnie - hipotezy pomocnicze,

- cel rozprawy,

- zakres planowanych badań (podmiotowy, przedmiotowy i czasowy),

- przewidywane do wykorzystania metody badawcze, 
- przewidywane narzędzia badawcze,

- planowany plan pracy doktorskiej,

- $\quad$ wybrane, główne pozycje literatury fachowej.

W niektórych środowiskach naukowych przed formalnym otwarciem przewodu doktorskiego na Radzie Wydziału koncepcja rozprawy jest przedmiotem obrad, dyskusji na Radach Naukowych lub komisjach Rad Wydziału. Na tych posiedzeniach kierowanych przez prodziekana ds. nauki, samodzielni pracownicy razem z promotorem powinni w sposób kompleksowy rozpatrzeć tytuł rozprawy, proponowaną hipotezę, cele rozprawy i jej konspekt. Im więcej dyskusji i uwagi poświęcone będzie w początkowej fazie przygotowania założeń poszczególnych doktoratów, tym mniej zmian i korekt koncepcji nastąpi później - w trakcie pisania.

Od doktoranta wymaga się, aby był on w swoich poszukiwaniach, w stawianiu hipotez bardzo wnikliwy i dociekliwy. W początkowej fazie pisania doktoratu doktorant powinien wykazać się dobrą znajomością krajowej i zagranicznej literatury. Oprócz cytowań i wzorowaniu się na poglądach innych znanych autorytetów, pożądane jest, aby doktoranci wykazywali się próbą konstrukcji własnych definicji, wyborem trafnych i skutecznych metod badawczych, aby w badaniach rynkowych dobierali odpowiednie próby badawcze, aby w obróbce materiałów źródłowych korzystali z dostępnych pakietów (np. Statistica, Statgraf, SPSS i inne). W realizacji tematów rozpraw z szeroko rozumianej ekonomii, z nauk organizacji i zarządzania, z finansów od doktorantów oczekuje się, że ich koncepcje oraz przyjęta metodyka rozwiązania konkretnego problemu badawczego była poparta odpowiednimi pracami analitycznymi (por. Pieter, 1974, s. 18 i n.) oraz próbą wykonania syntezy. Przed wykonaniem syntezy lub budową modelu doktoranci powinni poszukiwać związków i zależności głównych determinant. Autor niniejszego artykułu (por. Perenc, 1975, s. 1-292) w swoim doktoracie był zobligowany do wykonania badań związków korelacyjnych, wykorzystania metod analizy progowej, wykorzystania metod masowej obsługi do ustalenia pożądanego potencjału składników infrastruktury liniowej i punktowej. Dopiero wykorzystanie kilku metod badawczych oraz weryfikacja tych metod na podstawie wykonanych obliczeń pozwoliła jej autorowi na przedłożenie realistycznych determinant kształtowania składników infrastruktury w wybranych gałęziach transportu.

M. Sławińska i H. Witczak (2012, s. 164; Mendel, 1996, s. 51) precyzując uwagi do konstrukcji rozpraw postulują, aby do cech poprawnej konstrukcji zaliczyć:

- prostotę i przejrzystość, tj. aby doktorat miał wytyczony kierunek badań i drogę dojścia do celu,

- zwięzłość i zwartość układu rozprawy, unikanie powtórzeń,

- harmonię objętościową, tj. zachowanie właściwych proporcji pomiędzy poszczególnymi rozdziałami budowanej rozprawy.

Obserwacja zrealizowanych doktoratów - najpierw w Politechnice Szczecińskiej a później od 1985 roku w Uniwersytecie Szczecińskim pozwoliła zauważyć, że część doktorantów napisało swoje prace awansowe o objętości przekraczającej nawet 300 stron. Ale oprócz tak obszernych prac zostały także napisane i obronione prace o objętości 180-240 stron. Objętość tych ostatnich, to efekt częstszego stosowania syntezy i większej dbałości o stronę merytoryczna prac. Na nieco większą objętość doktoratów godzą się promotorzy, gdy doktoranci wykonali duże badania rynku, gdy zostały wykorzystane oryginalne, niepowtarzalne metody badawcze. 
W doktoratach powinien przeważać tok rozumowania problemowy. Dla danego rozdziału rozprawy powinno być wykonane wprowadzenie do problemu, następnie powinien być przedstawiony stan faktyczny, opis i analiza istniejących rozwiązań oraz wynikające z danego problemu wnioski. W konstruowaniu wniosków zaleca się unikania wnioskowania warunkowego lub prawdopodobnego. Wyprowadzane wnioski powinny mieć potwierdzenia w wynikach wykonanych badań oraz w analizach statystycznych na zebranym materiale empirycznym.

\section{WYMOGI OGÓLNE STAWIANE ROZPRAWOM DOKTORSKIM ORAZ OCENA SPRAWNOŚCI KSZTAŁCENIA}

Aktualnie obowiązująca ustawa Prawo o szkolnictwie wyższym, Ustawa o stopniach naukowych i tytule naukowym oraz o zmianie niektórych ustaw z 14.03.2003 r. ( Dz. U nr 84, poz. 455) oraz Rozporządzenie MNiSW z 30.10.2015 r. w sprawie szczegółowego trybu i warunków prowadzenia czynności w przewodzie doktorskim precyzują szczegółowo warunki wszczęcia procedury doktorskiej, warunki które powinien spełnić kandydat do stopnia doktora oraz szczegółowy tok postępowania przez Rady Naukowe poszczególnych wydziałów lub jednostek PAN. W art. 13 ust.1 jest sprecyzowany wymóg, że: „rozprawa doktorska powinna stanowić oryginalne rozwiązanie problemu naukowego lub oryginalne dokonanie artystyczne oraz wykazywać ogólną wiedzę teoretyczną kandydata w danej dyscyplinie naukowej oraz umiejętność samodzielnego prowadzenia pracy naukowej lub artystycznej”.

Dodatkowym warunkiem wszczęcia przewodu doktorskiego jest wydrukowana lub przyjęta do druku publikacja naukowa - monografia lub artykuł w recenzowanym czasopiśmie. Praca doktorska w naukach ekonomicznych powinna stanowić samodzielny dorobek danego autora. W niektórych sytuacja może być realizowany doktorat przez dwóch autorów, ale jest wtedy wymagane wyraźne określenie wkładu poszczególnych autorów (np. rozdz. 1 i rozdz. 2 - autor pierwszy; rozdz. 3, rozdz. 4 - autor drugi). Doktorant powinien systematycznie współpracować ze swoim promotorem na seminariach doktorskich i konsultacjach, przedstawiać kolejno napisane rozdziały swojej rozprawy, wykonywać poprawki i uzupełnienia zalecane przez promotora. Twórcza i kreatywna praca doktoranta powinna znaleźć odzwierciedlenie w doborze materiału teoretycznego i empirycznego, we właściwym doborze metod badawczych. Pisane rozprawy powinny mieć charakter naukowy, być samodzielne i rozwiązywać określony problem naukowy. Doktoranci swoją pracą, wykonanymi badaniami, umiejętnością poprawnego wnioskowania powinni wnosić do „skarbnicy wiedzy” cząstkę swoich dokonań.

Po napisaniu doktoratu i jego przyjęciu przez promotora wyznaczani są dwaj recenzenci spoza danej jednostki organizacyjnej, przeprowadzane są egzaminy doktorskie (z ekonomii, socjologii i języka obcego). Należy zadbać też o umieszczenie na stronach internetowych CKK streszczenia danej rozprawy oraz wykonanych recenzji. Po stwierdzeniu, że recenzje są pozytywne, Rada Naukowa danej jednostki ustala termin publicznej obrony. W obronie powinien wziąć udział minimum jeden z recenzentów oraz wyznaczona komisja przewodu doktorskiego lub cała Rada Naukowa. Po przeprowadzonej obronie następuje nadanie stopnia doktora w danej dyscyplinie wiedzy.

Obserwacja kilku edycji dziennych i zaocznych studiów doktoranckich na Wydziale Zarządzania i Ekonomiki Usług Uniwersytetu Szczecińskiego pozwala zauważyć, że stosunek obro- 
nionych prac doktoranckich do liczby studiujących na studiach doktoranckich maleje. Porównując sprawność zajęć w Politechnice Szczecińskiej i w Uniwersytecie Szczecińskim można zauważyć, że w latach 1971-1984 sprawność i liczba obronionych doktoratów wynosiła około 25-35\%, zaś sprawność w latach 1995-2010 zmniejszyła się do 15-18\%. Jeżeli na dany rok przyjmowano około 20-25 słuchaczy zaocznych studiów doktoranckich, to w ciągu 4 lat od rozpoczęcia tych studiów do obrony przystępowało około 3-6 doktorantów. Rady Naukowe na prośbę zainteresowanych słuchaczy przedłużały o dodatkowe 2-3 lata procedurę zakończenie pisania i termin obrony przedłożonych do oceny i recenzji prac doktorskich. Na zmniejszenie skuteczności studiów doktoranckich wpływały następujące przyczyny:

- niski poziom wsparcia doktorantów przez pracodawców,

- duże zróżnicowanie kandydatów,

- niska wiedza fachowa oraz utrudniony dostęp do światowych osiągnięć w danej dyscyplinie wiedzy, podejmowanie się przez doktorantów zbyt trudnych i pracochłonnych tematów rozpraw,

- odmowa lub utrudnianie przez badane podmioty gospodarcze badań empirycznych,

- ograniczenie puli środków finansowych na stypendia doktoranckie, którymi dysponują szkoły wyższe,

- $\quad$ zbyt skromna liczba staży i praktyk zagranicznych dla uczestników studiów doktoranckich.

Oprócz wskazanych wyżej, obniżona skuteczność studiów doktoranckich spowodowana jest zbyt małą aktywnością podczas studiów doktoranckich oraz zbyt niskim poziomem współpracy doktorantów z promotorami.

\section{PODSUMOWANIE}

Z rozważań zawartych w niniejszym artykule można wysnuć następujące wnioski:

Od 1971 roku uruchomiono na Politechnice Szczecińskiej tryb studiów doktoranckich zaocznych, a od 1985 roku w kolejnych latach zgłaszało się na nie około 20-40 kandydatów.

Od 1985 roku Uniwersytet Szczeciński uruchomił dzienne i zaoczne studia doktoranckie. Rocznie przyjmowano na III poziom tych studiów od 18-24 słuchaczy, zaś kończyło je terminowo około 3-6 doktorantów.

Rozprawa doktorska powinna stanowić oryginalne rozwiązanie problemu naukowego, wykazywać ogólną wiedzę teoretyczną kandydata w danej dyscyplinie naukowej oraz umiejętność samodzielnego prowadzenia pracy naukowej.

Na zmniejszenie skuteczności studiów doktoranckich wpływały głównie:

- mała pomoc pracodawców doktorantów we wspieraniu swoich pracowników,

- duże zróżnicowanie umiejętności poszczególnych kandydatów w zakresie metodyki prowadzenia prac naukowych,

- mała wiedza fachowa oraz utrudniony dostęp do światowych osiągnięć w danej dyscyplinie wiedzy,

- podejmowanie się przez doktorantów zbyt trudnych i pracochłonnych tematów swoich rozpraw doktorskich. 


\section{LITERATURA}

Blaug, M. (1995). Metodologia ekonomii. Warszawa: PWN.

Mendel, T. (1996). Metodyka pisania prac doktorskich. Poznań: AE.

Leśkiewicz, Z. (1990). Paradygmat racjonalności w gospodarowaniu. Szczecin: Wydawnictwo Naukowe US.

Leśkiwicz, Z. (1994). Racjonalność w ekonomi. Szczecin: Wydawnictwo Naukowe US.

Pieter, J. (1974). Z zagadnień pracy naukowej. Warszawa: PWN.

Perenc, J. (1975). Zależności pomiędzy wielkością i struktura potrzeb przewozowych a infrastruktura transportu (maszynopis powielany). Szczecin: Politechnika Szczecińska.

Sławińska, M., Witczak, H. (2012). Podstawy metodologiczne prac doktorskich w naukach ekonomicznych. Warszawa: PWE.

Zakrzewski, Z. (1973). O pracy doktorskiej w naukach ekonomicznych. Poznań. 